\title{
Title IX Then and Now at Old Dominion University: Listening for the Echoes
}

\section{Brendan O'Hallarn, Angela Eckhoff, and D’Andra Seymore Old Dominion University}

\begin{abstract}
Old Dominion University celebrates its pioneering role in addressing the landmark federal gender equity legislation known as Title IX, noting with pride that it was among the first universities in the country to offer scholarships for female studentathletes. What the popular portrayal of Old Dominion as a trailblazer misses is the internal struggle over gender-equity issues within the University at the time Title IX was being implemented. A 1975 letter discovered in the Old Dominion University Archives and Special Collections provides unique insight into that conflict, and offers an opportunity to analyze the University's commitment to gender equity through both a historical and modern lens. A hermeneutical analysis of the 40-year-old letter was used to inform a question line for six modern-day female administrators at the University. Echoes of 1975 are plentiful in their words, and offer new insight into how gender-equity struggles have changed through the decades in higher education.
\end{abstract}

Keywords: Title IX; college athletics; gender equity; liberal feminism; hermeneutical inquiry

It didn't matter that nobody had heard of Old Dominion. I wanted to be a part of building something great so that years later people would remember ODU and Nancy Lieberman, her teammates and their awards and accomplishments... We told everybody in the nation that the best place to be in women's college basketball was Old Dominion. (Lieberman \& Jennings, 1992, pp. 54-55)

The words of Nancy Lieberman reflect her immense pride in Norfolk, Virginia's Old Dominion University (ODU) becoming an unlikely titan in women's college basketball. Lieberman, Inge Nissen, and Ann Donovan were among the many stars who helped ODU win three women's national championships in a seven-year span, a surprising feat for the university with a modest national profile (Brydges et al., 2000). Without affiliation in a major athletic conference Old Dominion University has won 28 national championships in the past 40 years (ODUSports.com, 2015), the vast majority by female student-athletes. Credit for the accomplishment has 
been given to the University for its early and enthusiastic adoption of the genderequity legislation popularly known as Title IX (Minium, 2002; Sweeney, 1980).

Old Dominion University celebrates its pioneering role in providing equality and support to female student-athletes, as it was among the first schools in the country to incorporate the tenets of Title IX into its athletic planning (Brydges et al., 2000; Sweeney, 1980). In a 1999 interview with University Archivist James Sweeney, University President Alfred B. Rollins explained why it was important for the University to take tangible steps to end sex discrimination when he was president. Rollins said that investment in University athletics demonstrated how gender equity could be a significant benefit:

People interested in athletics were among the strongest supporters of the University at that point. But there was a sub-agenda that particularly appealed to me, and that was the development of women's athletic programs ... I'm 77 years old-and I'd come up through the women's movement. My first wife was denied the opportunity to go to graduate school because she was a woman. She went to the University of Connecticut, and they simply wouldn't recommend her because they said, "This is a waste of scarce resources." . . I I came here after, with a strong feeling of support for women's rights and I tried to play a strong role in the development of equality for the faculty and staff with the development of the Women's Center and, of course, the women's basketball program. And it took some doing at the start to convince everybody of these things. (Rollins, 1999)

Rollins spoke frequently about his determination to promote gender equality at the University, something which was highlighted in his obituary in 2013 ("Former ODU President," 2013). Documents in the University Archives show, however, that his actions were not solely proactive. Correspondence at the time with the Faculty Women's Caucus, and in particular cofounder Carolyn H. Rhodes, associate professor of English, (Crawford, 1976; Rhodes, 1976; University Women's Caucus Records, 1976-77), suggests ODU was dragged, somewhat reluctantly, to its position of eagerly embracing equal rights and opportunities for women, especially before Rollins assumed his role as University president.

This paper will demonstrate that the actual implementation of Title IX at ODU was not as positive as its modern reframing. A letter written to University administrators more than 40 years ago by Rhodes offers new insight into the struggle for gender equality at ODU. It contradicts the University's stated portrayal as a Title IX trailblazer, and helps inform modern-day interviews with six senior female administrators at the University. The study, which comprises both archival analysis and modern-day case study interviews, demonstrates there are dramatic differences, but also striking similarities, between 1975 and 2015 in the quest for true equality for women in collegiate settings. This research can provide further insight into a complex law, and contribute to our overall understanding of both this time period, and how the evolution of Title IX has affected gender-equity activities today.

The current study adds to the body of literature about women and sport, Title IX and colleges and universities, and examines Old Dominion University's Title IX performance through a liberal feminist framework. Title IX compliance by federally funded institutions has been examined as different strains of feminist theory (Brake, 2007), but liberal feminism's emphasis on working to alter existing power structures 
from within (Szczepaniak, Pathan, Sohail, \& Lohar, 2013) makes it well-suited for this study. Though times have changed, many of the same power structures still exist within Old Dominion University. In the present responses are clear echoes of the struggles of Rhodes and her contemporaries. Since application of Title IX is an issue faced by every college and university in the United States, lessons learned by Old Dominion University could be instructive in any postsecondary setting.

\section{Literature Review}

\section{Title IX}

Title IX of the Education Amendments of 1972 is a statement of fewer than 50 words that has had a powerful impact on higher education across the United States. It reads: "[n]o person in the United States shall, on the ground of sex ... be subject to discrimination... under any program or activity conducted by a public institution of higher education, or any school or department of graduate education, which is a recipient of Federal financial assistance" (Cong. Rec., 1971). Title IX, signed into law by President Richard Nixon June 23, 1972 scarcely mentions university athletics (Suggs, 2005), yet the vast majority of attention paid to the legislation pertains to the goal of equal treatment for female university athletes. Few university athletic departments are allowed to receive federal aid, but that aid flows to nearly every university in the country, meaning they must comply with Title IX (Minium, 2002).

The law prohibits discrimination on the basis of sex in three general areas: (a) exclusion from participation; (b) denial of benefits; and (c) discrimination under any education program or activity. This third area focuses specifically on unequal treatment, sexual discrimination, and harassment within federally funded programs (Richman, 2011). Despite Title IX being signed into law by President Nixon in 1972, the debate about the landmark legislation continued long after. The courts adjudicated dozens of cases about the specific application of the gender equality law. Congress did not clarify Title IX's impact on an educational institution until the 21st Century (Anderson, 2012). Kuznick and Ryan (2008) note that Title IX is a legal reform effort which seeks to change long-held understandings of the operation of gender roles in educational environments. They note it is important to carefully consider in its implementation the need to guide future legal agendas pertaining to gender equity.

Title IX's impact has been felt in different areas during its 40-plus years of existence. What started as legislation about equality of opportunity and income parity has been considered largely through the scope of its impact on athletics. More recently, Title IX scholarship has zeroed in on the responsibility of federallyfunded educational institutions with regards to sexual harassment and sexual assault. Silbaugh (2015) argues that college campuses have not used Title IX to its full capacity to prevent and reduce incidents of sexual assault. The investigation of nearly 100 colleges and universities nationwide for violations of Title IX in areas of sexual harassment and assault (Kingkade, 2015) suggests that the institutions are not properly applying the legislation (Sullivan, 2015). The fact that the reach and scope of Title IX has changed so dramatically over more 43 years has itself been the subject of scrutiny, including criticism of new Title IX regulations governing campus sex (Gavora, 2015). Britt and Timmerman (2014) argue that 
movement toward true equality still needs to occur in areas of leadership, the role of university boards and committees in reviewing policies and laws relating to Title IX compliance, turnover for female faculty because of unequal opportunities for advancement, and issues of risk management, particularly relating to sex assault. This reflects both the enormity of the change mandated by the groundbreaking legislation (Suggs, 2005), and the complexity and many different stakeholders present in a modern university landscape, whose needs and desires are frequently in conflict (Hums, 2007; Kingkade, 2015; Sullivan, 2015).

\section{Title IX at Old Dominion University}

Old Dominion University began its athletic programs the year it opened in 1930 as the Norfolk Division of the College of William and Mary (Sweeney, 1980). Despite spending its first 30 years as a two-year junior college, teams from the institution competed in a variety of sports, from baseball, to football (from 1930-41), to basketball. Intercollegiate sports were largely confined to men, however; women at the institution participated almost exclusively in intramural competitions (Brydges et al., 2000). Nationally, the Association for Intercollegiate Athletics for Women (AIAW) was formed in 1971 to provide and govern college opportunities and equality for women in sports (Cohen, 1993). Old Dominion fielded teams in AIAW competitions. In 1974, ODU's Board of Visitors adopted a comprehensive athletic program developed by Athletic Director Dr. James Jarrett, in consultation with the coaching staff. In addition to promoting the University's athletic programs to Division I, "another goal of the athletic plan was the upgrading of women's athletics. For the first time, women athletes would receive scholarships. Women's basketball was designated a 'high priority' sport that would receive full support" (Sweeney, 1980, p. 113). The following year, the inaugural Donna Doyle Smith Scholarship basketball game was held, the first event specifically hosted to put "emphasis on raising money for women's scholarships" (Brydges et al., p. 166). By 1976, every women's varsity team at Old Dominion University would receive one Donna Doyle Smith Scholarship annually. The small athletic department also added its first female coaches, including 23-year-old Marianne Stanley, who would become the most successful basketball coach in the University's history, male or female ("Marianne Stanley profile," n.d.). This early adoption of the female athletic scholarship allowed Old Dominion to recruit athletes such as Lieberman and Donovan, both considered the best girls' high school basketball player in the United States when they committed to ODU. The Lady Monarchs became a national power in basketball, winning three national titles in a seven-year span, starting in 1979 (Brydges et al., 2000). Lieberman is among the highest-profile athletic alumni of Old Dominion University, playing and coaching professional basketball and appearing as a television commentator for the sport (NancyLieberman.com, 2015).

More than 40 years after these successes for Old Dominion University Athletics, artifacts in the University Archives and Special Collections convey a different image of that time of great social change. Title IX in the mid-1970s was focused on remedying injustice away from the playing fields of sport. And at the time that Title IX was passed into law, female faculty and staff members were not represented at Old Dominion in anywhere close to the number, and at the level, of their male counterparts. A 1974-75 report by Institutional Studies for ODU teaching faculty 
found that out of 97 full professors at the University, only five were women. As a whole, only $20 \%$ of 459 faculty members were female (University Women's Caucus Records, 1976-77).

The ODU Faculty Women's Caucus was cofounded by Rhodes and Dorothy Johnson of the History department in 1974, to advance the welfare of women throughout the University. In a 2009 interview, Rhodes recalled the growing unrest among female faculty and staff members in the 1970s, a few years after Old Dominion College achieved University status. "We would unofficially be wary about systematic unfairness that we thought was happening, particularly hiring practices, and made some gestures like questioning differences in renewing instructors' contracts-men were more likely [to be retained] than women" (Rhodes, 2009). Rhodes said females were far less likely to be hired, promoted and earn tenure than their male counterparts. A comprehensive survey of faculty members conducted by the Women's Caucus confirmed that female faculty members earned, on average, $\$ 1,000$ less per rank than their male counterparts, which amounted to about $15 \%$. The survey findings were presented to then-President James Bugg. "He didn't respond at all," Rhodes (2009) said. And frustrations continued in the next few years, as the Women's Caucus attempted to amplify that point:

(I)n those years of frustration, there was a little development. It developed from nothing to denials, fervent denials, and then promises to work up the facts and give them to us. Meanwhile, not enough happened. We kept busy persuading our colleagues and our chairs and our deans to bring feminists to campus for workshops and lectures. We kept going to our caucuses and other organizations, like our professional ones, and generally trying to consciousness-raise on the campus while we were hoping to get something to happen. (Rhodes, 2009)

Rhodes said in the 2009 interview that administration resisted every entreaty by the Faculty Women's Caucus. Thus she upped the ante against the University, in a June 1975 letter best described as comprehensive and scathing. The correspondence, to "The ODU Committee on Compliance with Title IX, HEW," offered a stinging indictment of the University's performance in the three years since the initial passage of Title IX. Rhodes accused ODU administrators, notably Bugg and Provost Charles O. Burgess, of a "history of delays and denials" about three years of efforts by the Women's Caucus for attention to be paid to the issue:

Denials take the initial form of asserting that there is no problem, then later admitting that although there was indeed a problem, the most recent round of salary adjustments and instructions to department heads have taken care of it ... Women at ODU are over-represented at the bottom ranks, underrepresented at the top ranks, underpaid in many departments at all but the assistant professor rank and under-tenured in every department of every school except one or two. (Rhodes, 1975, p. 2)

The detailed, eight-page letter also articulated specific promises by senior ODU administrators that had not been kept, despite an investigation by the United States Department of Labor which discovered inequity of opportunities for female employees of the University (Rhodes, 1975). 
A story published in The Virginian-Pilot newspaper increased skepticism among female faculty members, after then-ODU President James Bugg declined to share salary information about the University (Crawford, 1976). The article also mentioned that the University was under a federal Department of Education investigation about salary discrimination since September 1975 (Crawford, 1976). Rhodes took her campaign public the next year, writing a letter to UNews (Rhodes, 1976) comparing salary and tenure by sex. In a February 1976 memo, Rhodes noted that "ODU administration has been consistently reluctant to provide data which aid in monitoring the status of women here" (Rhodes, 1976). Rhodes would continue to remain active in the Faculty Women's Caucus until her retirement from Old Dominion University in 1999 (Rhodes, 2009).

After Alfred B. Rollins accepted the presidency of Old Dominion University three months later ("Rollins accepts presidency," 1976) the tenor of the discussions around Title IX changed. A survey of sex discrimination faced by female faculty members was launched at ODU ("Survey of sex discrimination," 1976), with the report noting that the actions were "federally mandated" by Title IX. The procedure for the evaluation, created by the American Council on Education, was designed to be as inclusive as possible, outlining remedies for correcting discriminatory practices ("Survey of sex discrimination," 1976). Regular notices about the sex discrimination hearings were posted several times in UNews, until a final report was issued May 6, 1977. It was Rollins who insisted the University's Title IX report be published in its entirety in UNews. The report takes up four newspaper pages of the weekly UNews issue, and comprises background of the issue, the procedure for the University review, the summary of findings, and 18 specific recommendations ("Title IX report published," 1977).

Among the recommendations of the self-report committee were: (a) the employment of a full-time Affirmative Action director, reporting directly to the President; (b) implementation of the University's Affirmative Action Plan; (c) an "aggressive" attempt to identify and appoint and/or promote highly qualified female and minority faculty members; (d) an annual salary analysis be conducted by the Office of the Provost, and use outside consultants if there are conflicts; (e) a mandate that University departments hold more frequent staff meetings, soliciting feedback from both faculty and classified staff; and (f) any report by the Department of Labor concerning the University be forwarded to the Affirmative Action director as soon as it is received. Other recommendations cover issues such as release time for family matters, employee protection for pregnant workers, and the creation of an on-campus daycare, all issues articulated as concerns by the ODU Women's Caucus.

President Rollins himself authored the final section of the Title IX report, on implementation of the recommendations. He outlined the specific actions that had been conducted or planned to meet the recommendations, which he accepted in their entirety.

While I was not in office during the entire time you served as members of the Title IX Self-Evaluation Committee, I am well aware of the time and effort you gave to develop the report and recommendations. I am personally aware of the great efforts required of you during the open hearings. ("Title IX report published," 1977, p. 4) 
In summary, Rollins wrote that the University must continue to reevaluate its programs in light of the requirements of Title IX. "I am particularly concerned that all students have equal opportunities to enjoy the benefits of and participate in University-sponsored programs" ("Title IX report published," 1977).

\section{Title IX and Athletics}

Understanding the history of Title IX helps better characterize the legislation and its effects on society, including how it has shaped modern-day college athletics. Women played sports in college before Title IX became law but on a much smaller scale than today. (“Title IX @ 35," 2007). In 1970, two years before Title IX became law, there were only 2.5 women's sports played at each college and a total of 16,000 athletes. 2014 saw those numbers grow to 8.83 and more than 200,000 respectively (Acosta \& Carpenter, 2014). In 1972, the year Title IX was enacted, more than $90 \%$ of women's teams were coached by females. By the time mandatory Title IX compliance was implemented in 1978, the percentage had dropped to 58.2. By 2014, that figure had dropped to $43.4 \%$ (Acosta \& Carpenter, 2014). The figure for athletic administrative staffs is even lower, at 36.2\%, and in 2014, Acosta $\&$ Carpenter reported that $11.3 \%$ of athletic programs have no female employees anywhere in their administrative structures.

The durable narrative about Title IX, reinforced during ESPN's Nine for IX documentary series released on the 40th anniversary of the legislation (Ball, 2013), is that Title IX helped female athletes achieve hard-won gains. Less discussion has been held about discriminatory actions by other employers and organizations that receive federal funding. Hums (2007) notes in Women as leaders in sport: Impact and influence, that since Title IX, most colleges have merged their men's and women's athletic departments, and many women administrators were replaced by males in the same position. Scholarship about Title IX has pinpointed problem areas in the legislation's implementation, such as sexual assault (Spies, 2006; Walker, 2010), equality of opportunity (Mabry, 2013), and its effect on Olympic sports (Eagleman, Burch, \& Vooris, 2014) and high school sports (Stevenson, 2007). Despite these administrative challenges, Title IX has been an unqualified success in the courtroom. Cases such as Cannon v. University of Chicago (1979), Grove City v. Bell (1984) helped from the terms of the law's implementation, and the Supreme Court ruling Franklin v. Gwinnett County Public Schools (1992) was the first to give real power to Title IX, and threaten schools that weren't in compliance with the law (Suggs, 2005).

The issue of Title IX compliance for colleges and universities has been examined as an extension of different strains of feminist theory, including liberal feminism, special treatment, structuralism, dominance feminism and different voice feminism (Brake, 2007). The primary goal of liberal feminism is gender equality in public settings, such as equality of access and equal pay, and the major obstacle to that equality of opportunity is the domination of institutions by men (Jaggar, 1983), making it of particular pertinence to this study. Equality of opportunity has been fought over and won in the nation's courts, especially in connection with Title IX (Suggs, 2005). Liberal feminist theory suggests that females working within the structure of the college and university setting can effect real change. The measure of success at achieving such aims by liberal feminists under Title IX 
is the matter of some debate (Burke, 2005). Some studies suggesting adherence to liberal feminist tenets has offered greater opportunities for female athletes, coaches, and administrators (Paule-Koba, Harris, \& Freysinger, 2013). Other theorists posit that attempting to reform the system from within through distributive or procedural justice has resulted in Title IX's stated aims not being met (Lovett \& Lowry, 1995).

The different thrusts of research demonstrate how Title IX has been investigated extensively in the intercollegiate setting, including in the pages of this journal. However, each study raises new questions for researchers to answer. In their examination of athletic administration career prospects, Bower and Hums (2013) found that female employees credited Title IX for affording them more career opportunities, while some men blamed the legislation for discrimination against male employees. The authors suggest more research is needed to further examine these perceived impacts and their impact on the culture within an intercollegiate athletic program. In a single-institution analysis like the current study, a case examination of the elimination of sports at James Madison University found that action was precipitated more by an overall increase in athletic spending than mandates for equal participation opportunities for men and women (Staurowsky, Murray, Puzio, \& Quagliariello, 2013). The authors suggested more research could be useful into the latitude that schools have to choose their own priorities under Title IX. Finally, in a comprehensive review of sport leadership research, Burton (2015) suggested more research could help better explain why-despite the increased participation opportunities created by Title IX - females are still underrepresented in leadership positions in all levels of sport. She suggested scholars "continue to examine the impact of gender roles and stereotyping of leadership positions on women's perceptions of their leadership abilities in sport organizations" (Burton, p. 163). The literature suggests more scholarship about the complex dynamics within sport organizations, framed by the history of past actions of lawmakers and administrators, could provide a useful contribution to Title IX scholarship. The present study is an attempt to further unpack a very complex law, with the additional benefit of exploring both the past and present of Title IX.

\section{Liberal Feminism and Sport}

Liberal feminists share the traditional liberal view that freedom is a fundamental value, and focuses on women's ability to maintain their equality through their own actions and choices (Szczepaniak et al., 2013). Facing institutions and power structures historically gender-biased against, them, liberal feminism seeks to transform existing structures so that power and opportunity is shared along gender lines (Jaggar, 1983). Liberal feminist theory spans the spectrum of society, from politics to pop culture to children's toys (Eschle \& Maiguashca, 2014; Messner, 2000; Zaslow \& Schoenberg, 2012).

Feminist legal theory is a helpful tool for understanding the successes and limitations as Title IX as a vehicle for social change (Brake, 2010). Feminist legal scholarship has frequently marginalized sport, but several high profile cases connected to the quest for equality and access for female athletes, coaches, and administrators under Title IX have brought that critique of feminist theory into a sharper focus (Brake, 2010). The accelerated participation of female athletes, coaches and administrators has been seen as the manifestation of liberal feminism 
in the athletic realm (Burke, 2005; Scraton \& Flintoff, 2002). The liberal feminist framework has also been used in characterizing the demand from aspiring women that colleges and universities comply with the tenets of Title IX, affording greater opportunities for participation in female athletics (Boutilier \& SanGiovanni, 1994; Paule-Koba, Harris, \& Freysinger, 2013), how sports is marketed (Esmonde, Cooky \& Andrews, 2015), and advocated for (Barnett \& Hardin, 2011). Not all scholarship suggests Title IX has been an effective vehicle for women's equality as proscribed by liberal feminist theory. Lovett and Lowry (1995) submit that while liberal feminists correctly note the increase in funding and opportunity can be ascribed to the passage of Title IX, legislative and administrative action in colleges and universities falls far short of the equality of opportunity called for by theorists. Brake (2007) suggests the liberal feminist approach has met with mixed success, noting that quality insofar as women situated as varsity athletes has largely been reached, whereas the prominence of athletic identity in gender opportunity has resulted in second-class-citizen status being afforded women's sports.

As both Carolyn Rhodes in 1975 and the modern Old Dominion athletic officials operate within the university itself, their actions can best be framed through the lens of liberal feminism. The current study seeks to ground the findings, both from the letter written by Carolyn Rhodes, and the interviews with modern day female officials at Old Dominion University, in liberal feminist theory. Informed by Title IX, liberal feminism and Old Dominion University's unique experience with the legislation, this study is guided by the following questions:

RQ1 - What does the 1975 letter by Carolyn H. Rhodes to the ODU Committee on Compliance with Title IX illustrate about the climate for genderequity at Old Dominion University at the time?

RQ2 - Through their interviews, how do modern-day female administrators, in Old Dominion Athletics and the University at large, feel the University is performing with relation to Title IX's stated goals and objectives?

RQ3 - What similarities and differences exist in the characterization of the University's performance on gender equity between the modern-day interviews and the 1975 Rhodes letter?

\section{Method}

This study relied on both archival information and modern-day interviews, seeking to generate a then-and-now picture of Title IX at Old Dominion University. Together, they comprise a case study examination of ODU's commitment to gender equity, and require multiple qualitative methodologies. The letter by Rhodes provides a unique avenue through which to investigate Title IX at Old Dominion University, both in a historical and modern context. The letter itself offers a front-row view to the main points of friction between advocates of gender-equity and the University more than 40 years ago — employment equity, salary equity, equity of opportunity. It also affords an opportunity to help ground a line of interview questions for modern day female administrators at the University. Together, these analyses comprise a case study examination of ODU's commitment to gender equity, and require multiple qualitative methodologies. 
Case studies are ideally suited for an in-depth examination of a bounded site or set of circumstances, seeking to explore greater truths (Yin, 2014). Case study is useful in this particular case because, as Bylund (2003) notes, they focus on contemporary events and do not require behavioral control (Bylund, 2003). Case studies provide the opportunity for researchers to unpack meaningful patterns within narratives (Babrow, 1995; Matsunaga, 2007). A then-and-now examination of Old Dominion University's response to Title IX is also appropriate in this instance because case study research is an iterative process, where new research informs additional insight in existing data (Yin, 2014). This methodology is specifically informed here, because the historical documents were analyzed before and after the modern-day interviews were conducted and analyzed.

For this study, multiple qualitative methodologies were used to draw deeper meaning from both historical documents and modern-day interviews. The Old Dominion University Archives and Special Collections illustrate the paradox in the modern characterization of ODU as a Title IX trailblazer, information which was analyzed by two of the researchers. The University's successes in athletic equality are amplified (Brydges et al., 2000; Rollins, 1999). But other historical material in the Archives demonstrates the struggle for equality in the 1970s (Rhodes, 1976; "Survey of sex discrimination," 1976; University Women's Caucus Records, 1976-77). Those issues are encapsulated in dramatic fashion in the Rhodes letter. This eight-page Rhodes letter, which addresses a large number of grievances about the delays of University administration, provides a concise, yet comprehensive document for case study analysis. The letter represents a bounded data artifact that provides a powerful snapshot of gender equity in 1975, something which could inform the modern-day question line, and then act as a point of comparison for the themes that emerge from the interviews.

Informed by knowledge gained from the University Archives and media coverage about the evolution of Title IX at ODU, a hermeneutical analysis was conducted on the letter to University administration by Rhodes. Hermeneutical analysis informs qualitative inquiry by suggesting the meaning of an artifact depends "on the cultural context in which it was created, as well as the cultural context in which it is subsequently interpreted" (Patton, 2002, p. 113). It offers a perspective for interpreting historical texts to understand meanings and place documents in a historical or cultural context (Palmer, 1969). Researchers use hermeneutical methods to establish context and meaning for what people do. Kneller (1984) suggests four principles to apply to hermeneutic inquiry: (a) understanding human acts, and all learning, is like interpreting a text; (b) all interpretation occurs within a tradition; (c) interpretation involves a researcher opening themselves to a text and questioning it; and (d) text must be interpreted in light of a researcher's particular situation.

Hermeneutical inquiry is particularly interested in the how written communication creates its own communication pattern, or discourse, giving greater meaning to the words through both their context and articulation (Ricoeur, 1973). This method of inquiry has been used across many disciplines of the social sciences, including in the research of sport, providing evidence of the denial of power in televised women's sports (Duncan \& Hasbrook, 1988) and examining spectator sport during the 1976 and 1984 Olympic Games (Duncan, 1986). The essence of this method of inquiry is the hermeneutic circle, where parts of documents are interpreted as a component of the whole, and understanding of the whole better informs each 
individual part (Packer \& Addison, 1989). This approach is well-suited for this study, which looks at the past, the present, then reflects back to the past, because by its creation, hermeneutic inquiry is not affixed to a central design. The analysis is better considered as a resting point for scientific inquiry, open to new interpretations as more information is added to the analysis (Packer \& Addison, 1989).

Concurrent to the hermeneutical analysis for this particular case study, interviews were conducted with female members of the university community, both inside and outside of the athletic department. The preponderance of academic study and popular press coverage of Title IX has concerned intercollegiate athletics, but the Department of Education legislation encompasses the full range of gender equity issues, from issues of access and opportunity, to salaries, to sexual assault. Therefore semistructured interviews were conducted with female coaches and administrators from ODU Athletics, and senior female administrators from outside of Athletics. The question line was informed by information learned about the University's internal struggle with the new Department of Education legislation in the 1970s, as well as the modern-day perception that Old Dominion University has been a champion of gender equity issues among colleges and universities. The selection of six interview subjects allowed for a range of experiences to be reflected both within and outside of Old Dominion athletics. The six interviews were conducted in person by the lead researcher, in a one-on-one setting, and recorded. Two semistructured question lines were created, informed by the lead researcher's understanding of Title IX at Old Dominion University, and the Rhodes letter. The questions were reviewed by experts, and approved by the College's Human Subjects committee. The interviews, which ranged from 15 to 30 minutes, were recorded, transcribed and analyzed.

Content analysis is used to refer to any qualitative data reduction that attempts to induce core consistencies and meanings from a volume of qualitative material (Patton, 2002). When prior research exists about a phenomenon, which would aid in further describing data that is gathered for a study, a directed content analysis is well-suited (Hsieh \& Shannon, 2005). The goal of a directed approach is to extend conceptually a theoretical framework or theory — in this case, Old Dominion University's Title IX legacy expressed as an articulation of liberal feminism.

Following the six interviews, two researchers conducted independent, directed content analysis of the interview transcripts, independently identifying dominant content and themes (Potter \& Levine-Donnerstein, 1999). Through prior understanding of both liberal feminism and Old Dominion's Title IX experience, the researchers were able to create consensus codes linking the modern-day interviews with the existing theoretical framework (Hays \& Singh, 2011). Transcripts of the interviews and themes that emerged through the directed content analysis were member-checked with interview subjects, as an added layer of authenticity that the themes that emerged accurately represented interview subjects' intent.

As a final step, the consensus codes created during the directed content analysis of the modern-day interviews were overlaid with the initial hermeneutical analysis of the 1975 Rhodes letter. Consistent with the both the iterative process of case study research (Yin, 2014), and the lack of a final resting point for scientific inquiry that marks hermeneutical analysis (Packer \& Addison, 1989), revisiting the original letter afforded researchers an opportunity to reexamine more than 40 years of Old Dominion University's commitment to Title IX gender equity through the liberal feminist theoretical framework. 


\section{Results}

\section{The Rhodes Letter}

The hermeneutical analysis of the letter to "The ODU Committee on Compliance with Title IX, HEW" began with immersion in the eight-page document. In an effort to situate the document in the historical and cultural context in which it was written, information surrounding the status of Title IX as it stood in 1975 was gathered and synthesized before the analysis was conducted. An effort was also made to better understand the author herself, Carolyn Rhodes. Rhodes (1999) conducted a series of oral interviews with the Old Dominion University Archives, which were reviewed to gain a better understanding of her before the letter was analyzed.

Utilizing Packer and Addison's (1989) hermeneutic circle, the researcher identified six aspects to Rhodes' characterization of gender equity at Old Dominion: (a) the faculty women's caucus had previous experienced stonewalling from administration; (b) there existed at the time external and internal instances of inequality; (c) there was a lack of trust in administration; (d) more proactive steps were needed to deal with gender equity; (e) female faculty and staff at ODU needed to feel freer to advocate on their behalf; and (f) there is an opportunity to make a difference if appropriate actions are taken. The correspondence indicated three dominant thoughts about Title IX at Old Dominion University:

(a) Rhodes believed that there is inequality, it hadn't been addressed, and efforts to address it have been foiled. Examples include: "Women at ODU are overrepresented at the bottom ranks, underrepresented at the top ranks, underpaid in many departments," and "denials take the initial form of asserting that there is no problem, then later admitting that although there was indeed a problem, the most recent round of salary adjustments and instructions to department heads have taken care of it," and "the inequalities of the past have been perpetuated by chairmen engaged in unmonitored and uninformed self-evaluation."

(b) There was a lack of trust in administration to fix the problems that had been identified. Some examples of this from the letter: "The point is clear: assurances are not enough to prove equity," and "any committee concerned with the status and treatment of women at ODU should certainly interview at length some of the women who have collected, analyzed and distributed data about the status of women here."

(c) There is hope in Rhodes words, despite the criticism, that a solution to the unequal treatment of female faculty and staff existed within the University. Some examples: "There remain some significant things you can do, if you choose. You can suggest to department heads that they actually speak to the women in their departments before writing their Title IX reports," and "your committee can help to define and initiate a meaningful affirmative action program at ODU," and "ODU would gain great credibility by establishing an office dedicated to the concerns of minorities and women and actually serving those constituencies."

The Rhodes letter illustrates that in June 1975 there existed a sense of unequal treatment and climate of suspicion between female faculty leaders and University 
administration. Consistent with liberal feminist theory, Rhodes led an action-based response to the perceived mistreatment from within, prodding administration to make changes in the area of gender equity. Continuing Packer and Addison's (1989) hermeneutic circle to a natural pause in the analysis, the components of Rhodes' advocacy add up to her sense that Old Dominion University's commitment to gender equity under Title IX did not meet the spirit of the legislation, particularly with regards to fairness, access to opportunity, and freedom to advocate. Yet Rhodes remained optimistic about the potential of the University to play a leading role in gender equity among peer institutions.

\section{Modern-Day Interviews}

The six female officials selected to be interviewed have a combined 100 years of employment history at Old Dominion University. All but one still work for the University; one was a long-time employee who had recently retired. Their experience ranged from just over one year, to more than 35 . Three of the women work in Athletics. The other three work, or worked, in the main University administration. Before beginning analysis of interview transcripts, two of the study authors compiled a list of themes expected to emerge from the interview data, suggested for directed content analysis by Hsieh and Shannon (2005). The list of themes were assembled through analyzing the materials gathered from the University Archives and Special Collections, notably the letter by Carolyn Rhodes, an understanding of the history and legacy of Title IX, both nationally and at Old Dominion, and through the lens of liberal feminism. The following themes were predicted to emerge in the responses:

(a) The issue of equality, in terms of opportunity, salaries, promotion and fairness to women;

(b) The role of particular leaders at the University in promoting gender equality, notably former Athletic Director Jim Jarrett;

(c) Discussion about whether Old Dominion University was indeed a trailblazer with Title IX;

(d) The impact of the Faculty Women's Caucus, and Carolyn Rhodes, on the University; and

(e) The discussion of particular sports at Old Dominion, such as the dominant women's basketball teams, and the football program at the University, reintroduced in 2009 after a 70-year hiatus.

In a review of the data by both researchers, four of the five expected topics were mentioned significantly. The role of the Faculty Women's Caucus received only minor mention, and there was no unprompted mention of Carolyn Rhodes. Though Rhodes continued to work at the University until 1999, and remained active in the Faculty Women's caucus, the letter she wrote predated the start of employment for all of the interview subjects.

Interviewees, particularly those with longer tenures, articulated that the University's positive history with Title IX is something to be proud of. "We were a pioneer, a leader, a trailblazer, whatever word you want to use, in that we had very forward-thinking men at the time, who made some very bold decisions to start providing women the opportunity to excel in Athletics," one Athletics official 
said. Some respondents noted, however, that Old Dominion does not maintain its visionary status with Title IX, in Athletics or any other area. "In general, I think we are not trailblazers any more, but we uphold the tenants of Title IX in Athletics," said a respondent who works in University administration, noting that the number of female head coaches has declined. "I don't think we're where we were before, and I would like to see us there again." The recent retiree from University administration, said she spoke against the reintroduction of football at Old Dominion in 2009 , worrying about backward steps in gender equity. "I felt silenced quite a bit," she said. "I think there was an awareness that the drinking and the partying and the potential for sexual assault would increase." One non-Athletic official believed the University's positive gender equity legacy has been enhanced through what she termed the "powerful trifecta" of a standalone Women's Center, the Faculty Women's Caucus, and the Department of Women's Studies. "And I think it's a testament to ... ODU ... that we have those three entities, that they're all very strong separately, and together they're just a powerhouse."

A few themes that emerged in the interviews that were not anticipated by researchers include:

(a) The framing of cooperation and fairness with University and Athletic administration in generally positive terms, which certainly contrasts with the relationship portrayed by Carolyn Rhodes in her 1975 letter. "A few years ago, with the full support of the University, we brought in an attorney from another state to help guide us, guide the University, in sexual harassment training that was intended for the whole University," one administrator said. Another administrator spoke about the support for female athletic teams that is mandated from the top of University administration: "If you look at our facilities, they're incredible. Our female athletes participate in outstanding facilities, right alongside their male counterparts."

(b) Repeated mention that the University administration was responsive to concerns raised, even if the grievance raised wasn't completely addressed. A female University administrator noted that "we used to have some angst in our relationship and quite a bit of conflict" but that the Faculty Women's Caucus and administration have a "really good working relationship" and that the University President himself had asked her to come directly to him with any Caucus concerns, "and you don't have to have a big formal meeting for that to happen." An official in Athletics said: "I'm a part of the senior management; I have my say... Ultimately my input may not be what they chose to do." The recently retired administrator said the lack of perceived responsiveness from administration in earlier years might have been reflective of the fact that advocates weren't aware of how much clout Title IX actually carries. "I don't even really connect a lot of the work I was doing to Title IX," she said. "The fact that we didn't connect it so much to Title IX gave us less teeth in terms of pushing ... the administration to be more proactive on these issues."

(c) A final theme common to interview subjects both in and out of Athletics is worry that adhering to Title IX will prove more challenging in the future. New legislation passed by the Virginia Legislature in 2015 mandates that Old Dominion raise no more than $55 \%$ of its athletic revenues from student fees in the future (Minium, 2015). A veteran Athletics official said she worries not 
only about opportunities for female athletes, but also male nonrevenue sport athletes, with ongoing funding challenges. "And the sad state of it is women's athletics, at least here at this institution, don't generate a lot of revenue," she said. A female administration employee worries that the application of Title IX to investigations of sexual assault has led to more focus on reporting requirements and institutional control, and less support for victims. "There's a lot going on right now when it comes to the sexual violence piece of Title IX, and I think it's a moving target," she said. "Title IX is saying, 'You have to do this, and this, and this, and this,' and some of them can have a backlash effect."

\section{Reflecting Back on 1975}

The statements about Title IX's future reflect a strongly different vision of the potential to enact durable change. Despite Rhodes' extensive critique of the actions of University officials to date, her 1975 letter ultimately strikes a hopeful tone. She believed that the solutions to gender inequality could be found within the existing University administration. "I still believe that self-study can be thorough and honest and that internal agencies can resolve our problems," Rhodes wrote.

It is clear that nationwide, massive steps have been taken toward a more equal environment for women at the nation's colleges and universities. But four decades have passed since that letter was written and sent. That may explain why the modern-day interview subjects express concern about the future of Title IX. "It's important to keep reminding people that this is an important issue," one University administrator said. "Because it's not over and it's not done, as far as equality. I wish that Title IX fixed it all, but it didn't." Officials in Athletics say they are worried about the sustainability of the legislation, particularly in light of the new Virginia legislation mandating that Old Dominion reduce the percentage of its athletic budget funding from student fees to 55\% (Minium, 2015). "You just have to ... identify more people who might help a women's sport in some ways. You need more of those donations going on throughout the country."

\section{Discussion}

Since its passage in 1972, Title IX has been the subject of advocacy, scrutiny, legal challenges, and evolution in terms of its points of emphasis (Suggs, 2005). Argued in federal courts, debated by scholars, and implemented with some trepidation by many colleges and universities, the legislation remains controversial, and it is argued, its full potential has not been realized (Kuznick \& Ryan, 2008; Silbaugh, 2015). Studies of gender equity in college and university settings have involved nationwide surveys (West \& Curtis, 2006) and publications by a single organization (Barnett \& Hardin, 2010).

Much of the scholarship of Title IX has focused on intercollegiate settings, and each study suggests more opportunities for research-which is not surprising because of the complexity of the legislation. Studies about female employees in leadership positions (Burton, 2015), career opportunities for men and women in intercollegiate settings (Bower \& Hums, 2013), and even single-institution studies (Staurowsky et al., 2013) suggest that more research can help better explain why Title IX has been such a sweeping success in aspects such as participation rates and 
the legal realm, but has not delivered on its legislative promise in other instances (Burton, 2013; Esmonde, Cooky, \& Andrews, 2015).

In framing their examination of administrators at a single institution, a scope similar to this study, Paule-Koba, Harris and Freysinger (2013) note that "little research has examined how Title IX is perceived by the variety of individuals who comprise the communities of the institutions of higher education that have made changes to their athletic program offerings because of this legislation" (p. 116). That is where this study can add value to the body of sport scholarship on Title IX. The popular notion of Old Dominion University is as a Title IX trailblazer, yet the actual picture is more complex, with some successes, and some setbacks. This then-and-now investigation demonstrates that despite the passage of more than 40 years, the institution-altering changes brought about by Title IX are not complete.

This study made use of a unique point of access to the Title IX struggles of the 1970s on college and university campus through a letter written to University officials by Faculty Women's Caucus chair Carolyn Rhodes. The June 1975 letter, sharply critical of Old Dominion's response to Title IX to that juncture, explodes the commonly held perception that ODU was a trailblazer in gender equity among U.S. universities. While Old Dominion was among the first schools to offer women athletic scholarships, the letter suggests that, University-wide, gender-equity gains were hard won, as they have been in many workplaces. The letter also provided a unique vantage point to compare perceptions of the University and its commitment to gender equity then and now, comparing Rhodes' words with interviews with six modern-day female University officials.

It is clear that the circumstances being discussed in the 1975 letter from Carolyn Rhodes differ significantly from the issues being tackled today. Athletic scholarships for female athletes were only just beginning when Rhodes wrote angrily to administration. The use of Title IX as legislation to prevent sexual harassment and assault had not begun. But the broad themes of respect and cooperation, and looking forward at what Title IX can do, demonstrate a connection between the communications, four decades later.

Both the letter and the interviews discuss the issue of cooperation between gender-equity advocates and University administration, and in sharply different terms. Rhodes claim of a "history of denials" differs from the culture of cooperation that exists in the words of modern-day interview subjects. While there may still be points of friction, female University leaders say they feel far more equal. One Athletics official said: "I don't feel like a women's coach at Old Dominion; I feel like a coach."

It is no secret that university life is different in 2015 than it was in 1975. University student populations are more than $50 \%$ female nationwide (Gavora, 2015); faculty percentages are closer to parity as well, though not in senior ranks. In their study Organizing around gender equity, West and Curtis (2006) found that 34 years after Congress passed Title IX, women hold only $24 \%$ of full professor positions on U.S. campuses. Carolyn Rhodes and her contemporary gender-equity advocates fought for a larger role for female faculty and staff members, in terms of overall numbers, opportunity for promotion and wage equality (Rhodes, 1999). While steps have been made toward gender equity, modern-day advocates still fight for true equality. Modern day advocates are still seeking consideration of their concerns in a respectful fashion, they are still eager to forge relationships to work 
collaboratively on solving gender-equity issues, and they have concern about the future of these issues in a rapidly changing environment for higher education. In that way, though this study is confined to a then-and-now analysis of gender equity issues at Old Dominion, the themes are universal. It would be instructive for any institution faced with effective, ongoing implementation of Title IX protocols to learn from discussions a generation ago. What were the grievances? How were they addressed? What tools were the most effective at promoting a climate of harmony in the quest for true equality?

When you explore the words of Rhodes and the modern-day University leaders through liberal feminist ideology, you find seven individuals working diligently from within to impart meaningful change through their actions (Szczepaniak et al., 2013). The limitations of liberal feminism in effecting real change, because the advocacy occurs within existing male-dominated power structures (Lovett \& Lowry, 1995), is present in the words of some female officials, who worry about rocking the boat by advocating too aggressively. But the contact and access that working within an organization, suggested to be a benefit of liberal feminism (Jaggar, 1983, Paule-Koba, Harris, \& Freysinger, 2013), is also seen in the words of both Rhodes, and the modern-day subjects. It is their relationship with administrators, former athletic director Dr. Jim Jarrett and the current University president that allows for frank discussion, and airing of grievances. The limitations in making gravitational change from within expressed by the modern-day administrators (yet ironically, not Carolyn Rhodes) indicate that improvements are more likely to be incremental than seismic. However, 40 years of incremental changes can add up to a climate generally portrayed as more positive, which is seen in the modern-day interviews.

\section{Limitations and Suggestions for Further Research}

Like any single-organization study, the circumstances of Title IX's Old Dominion University history are not directly applicable to another college or university. However, the themes articulated by female administrators at Old Dominion University are universal to higher education in the United States, even if the particular circumstances of the gender-equity struggle at Old Dominion are unique to the school. The Rhodes letter that was analyzed for the hermeneutical analysis was comprehensive and scathing, however it was a letter, and follow-up questions could not be asked. Though the files pertaining to Title IX at the Old Dominion University Archives and Special Collections were analyzed thoroughly, including Rhodes' own personal collection, the information is 40 years old, and subject to the personal bias of the researchers who analyzed it. Clarification questions could not be asked, because the participants on the front lines of gender equity at Old Dominion in 1975 are no longer at the University. Former University President James Bugg died in early 2015 ("ODU's second president," 2015). It is clear that the abundant documentation that exists in the University Archives about issues surrounding gender equity (Crawford, 1976; University Women's Caucus Records, 1976-77) indicates that Rhodes' complaints were based in the reality of the working conditions for female employees at the University in the 1970s.

For further studies, just about every university in the country would have its own archival collection, chronicling the dynamic struggle for gender equality from a generation ago. Since the changes mandated by Title IX were seismic, there was 
probably a Carolyn Rhodes-type figure on many college and university campuses nationwide. Comparisons between officials at different universities, then and now, might yield greater insight into the perceptions of progress toward true equality. This study could also be extended to include female students, many of whom receive the benefits of the battles fought on their behalf by Carolyn Rhodes and others, long before they were born.

\section{References}

About Nancy Lieberman. (2015). NancyLieberman.com. Retrieved from http://www.nancylieberman.com/about/

Academic women's salaries approach equality. (1975, January 10). UNews. Retrieved from Special Collections of the Old Dominion University Libraries.

Acosta, R.V., \& Carpenter, L.J. (unpublished manuscript). Women in intercollegiate sport: A longitudinal, national study, thirty-seven year update, 1977-2014. Acosta/Carpenter. Retrieved from www.acostacarpenter.org

Amend. 398, (1971). 117 Cong. Rec., 30, 156.

Anderson, P.M. (2012). Title IX at forty: An introduction and historical review of 40 legal developments that shaped gender equity law. Marquette Sports Law Review, 22(2), 325-393.

Babrow, A. (1995). Communication and problematic integration: Milan Kundera's "lost letters" in the book of laughter and forgetting. Communication Monographs, 62, 283-300. doi:10.1080/03637759509376364

Ball, C. (2013, November 6). 'Nine for IX' documentary series on ESPN shows women athletes' struggle for equality. Cleveland Plain Dealer. Retrieved from http://www. cleveland.com/movies/index.ssf/2013/11/nine_for_ix_documentary_series.html

Barnett, B., \& Hardin, M.C. (2011). Advocacy from the liberal feminist playbook: The framing of Title IX and women's sports in news releases from the women's sports foundation. International Journal of Sport Communication, 4(2), 178-197. doi:10.1123/ijsc.4.2.178

Boutilier, M., \& SanGiovanni, L. (1994). Politics, public policy and Title IX: Some limitations of liberal feminism. In S. Birrell \& C. Cole (Eds.), Women, sport \& culture (pp. 97-109). Champaign, IL: Human Kinetics.

Bower, G.G., \& Hums, M.A. (2013). The impact of Title IX on career opportunities in intercollegiate athletic administration. Journal of Intercollegiate Sport, 6(2), 213-230. doi:10.1123/jis.6.2.213

Brake, D.L. (2007). Title IX as pragmatic feminism. Cleveland State Law Review, 513.

Brake, D.L. (2010). Getting in the game: Title IX and the women's sports revolution. New York: NYU Press. doi:10.18574/nyu/9780814799659.001.0001

Britt, M., \& Timmerman, M. (2014). Title IX and higher education: The implications for the 21st Century. Franklin Business \& Law Journal, 2014(1), 83-86.

Brydges, M., .... (2000). Old Dominion University: From the Great Depression to the new millennium, 1930-2000. Norfolk, VA: Old Dominion University.

Burke, M. (2010). A feminist reconstruction of liberal rights and sport. Journal of the Philosophy of Sport, 37(1), 11-28. doi:10.1080/00948705.2010.9714763

Burton, L.J. (2015). Underrepresentation of women in sport leadership: A review of research. Sport Management Review, 18(2), 155-165. doi:10.1016/j.smr.2014.02.004

Bylund, C.L. (2003). Ethnic diversity and family stories. Journal of Family Communication, 3, 215-236. doi:10.1207/S15327698JFC0304_4

Cohen, G. (1993). Women in sport: Issues and controversies. Newbury Park, NJ: Sage Publications.

Crawford, P. (1976, February 12). Is the question whether or how much? The Virginian-Pilot. Retrieved from Box 4, Folder 4: Title IX/Affirmative Action (1977-78), Old Dominion 
University Women's Caucus Records, Special Collections of the Old Dominion University Libraries.

Duncan, M.C. (1986). A hermeneutic of spectator sport: The 1976 and 1984 Olympic Games. Quest, 38, 50-77. doi:10.1080/00336297.1986.10483841

Duncan, M.C., \& Hasbrook, C.A. (1988). Denial of power in televised women's sports. Sociology of Sport Journal, 5, 1-21. doi:10.1123/ssj.5.1.1

Eagleman, A., Burch, L.M., \& Vooris, R. (2014). A unified version of London 2012: New-media coverage of gender, nationality, and sport for Olympics consumers in six countries. Journal of Sport Management, 28(4), 457-470. doi:10.1123/jsm.2013-0151

Eschle, C., \& Maiguashca, B. (2014). Reclaiming feminist futures: Co-opted and progressive politics in a neo-liberal age. Political Studies, 62(3), 634-651. doi:10.1111/1467-9248.12046

Esmonde, K., Cooky, C., \& Andrews, D.L. (2015). "It's supposed to be about the love of the game, not the love of Aaron Rodgers' eyes": Challenging the exclusions of women's sports fans. Sociology of Sport Journal, 32(1), 22-48. doi:10.1123/ssj.2014-0072

Former ODU President Alfred Rollins dies. (2013, February). News @ ODU. Retrieved from https://www.odu.edu/news/2013/2/alfred_rollins\#.VkCmYtIQVlU

Gavora, J. (2015, June 7). How Title IX became a political weapon. The Wall Street Journal. Retrieved from http://www.wsj.com/articles/how-title-ix-became-a-politicalweapon-1433715320

Hays, D., \& Singh, A. (2011). Qualitative inquiry in clinical and educational settings. Charlottesville, VA: Wiley.

Hsieh, H., \& Shannon, S. (2005). Three approaches to qualitative content analysis. Qualitative Health Research, 15(9), 1277-1288. PubMed doi:10.1177/1049732305276687

Hums, M. (2007). Women as leaders in sport: Impact and influence. Oxon Hill, MD: National Association for Girls and Women in Sport.

Jaggar, A.M. (1983). Feminist politics and human nature. Totowa, N.J.: Rowman \& Allanheld. Kingkade, T. (2015, January 7). Barnard College joins list of 94 colleges under Title IX investigations. The Huffington Post. Retrieved from http://www.huffingtonpost. com/2015/01/07/barnard-college-title-ix-investigations_n_6432596.html

Kneller, G.F. (1984). The movements of thought in modern education. New York: John Wiley.

Kuznick, L., \& Ryan, M. (2008). Changing social norms? Title IX and legal activism comments from the spring 2007 Harvard Journal of Law \& Gender Conference. Harvard Journal of Law \& Gender, 31(2), 367-422.

Law, J. (1974, September 20). Division I status will include women. UNews. Retrieved from Special Collections of the Old Dominion University Libraries.

Law, J. (1974, November 22). First athletic grants given to women. UNews. Retrieved from Special Collections of the Old Dominion University Libraries.

Lieberman, N., \& Jennings, D. (1992). Lady Magic: The autobiography of Nancy LiebermanCline. Champaign, IL: Sagamore Publishing, Inc.

Lovett, D.J., \& Lowry, C.D. (1995). Is liberal feminism working in the NCAA? Journal of Sport Management, 9, 263-272. doi:10.1123/jsm.9.3.263

Mabry, A.M. (2013). Title IX: Proportionality and walk-ons. The University of Memphis Law Review, 44(2), 497-522.

Marianne Stanley profile (n.d.). Old Dominion University Athletics. Retrieved from http:// www.odusports.com/ViewArticle.dbml?DB_OEM_ID=31100\&ATCLID=208424706

Matsunaga, M. (2007). Shaping, masking, and unmasking of stigmatized identity: The case of Japan-residing Koreans. The Howard Journal of Communications, 18, 221-238. doi:10.1080/10646170701490815

Messner, M. (2000). Barbie girls versus sea monsters: Children constructing gender. Gender \& Society, 14, 765-784. doi:10.1177/089124300014006004

Minium, H. (2002, June 21). Title IX: 30 years later. Gains made - at a cost. The VirginianPilot. Retrieved from http://infoweb.newsbank.com.proxy.lib.odu.edu/resources/doc/ $\mathrm{nb} /$ news/0F450A2D59C6B51E? $=$ AWNB 
Minium, H. (2015, May 28). As mandate looms, ODU relying less on student fees. The Virginian-Pilot. Retrieved from http://hamptonroads.com/2015/05/mandate-loomsodu-relying-less-student-fees

ODU's second president James Bugg passed away Jan. 15 (2015, January 21). Old Dominion University. Retrieved from https://www.odu.edu/news/2015/1/bugg_obit\#.VYWnAot_kuU

Old Dominion University national championships (2015). ODUSports.com. Retrieved from http://www.odusports.com/ViewArticle.dbml?ATCLID=208427177\&DB_OEM_ ID=31100\&DB_OEM_ID $=31100$

Packer, M., \& Addison, R. (1989). Entering the circle: Hermeneutic investigation in psychology. Albany: State University of New York Press.

Palmer, R.E. (1969). Hermeneutics. Evanston, IL: Northwestern University Press.

Patton, M.Q. (2002). Qualitative research and evaluation methods (3rd ed.). Thousand Oaks, CA: Sage Publications, Inc.

Paule-Koba, A.L., Harris, O., \& Freysinger, V.J. (2013). "What do I think about Title IX?" Voices from a university community. Research Quarterly for Exercise and Sport, 84(1), 115-125. PubMed doi:10.1080/02701367.2013.762323

Potter, W.J., \& Levine-Donnerstein, D. (1999). Rethinking validity and reliability in content analysis. Journal of Applied Communication Research, 27, 258-284. doi:10.1080/00909889909365539

Presidential search team to include faculty and students. (1975, September 12). UNews. Retrieved from Special Collections of the Old Dominion University Libraries.

Rhodes, C. (1975, June 14). Letter to the ODU Committee on Compliance with Title IX, HEW. Memos and Correspondence, Old Dominion University Women's Caucus Records, Special Collections of the Old Dominion University Libraries.

Rhodes, C. (1976, February 20). Salary and tenure compared by sex. UNews. Retrieved from Special Collections of the Old Dominion University Libraries.

Rhodes, C. (2009, March 27). Oral history interview with Dr. Carolyn Rhodes [Transcript and audio file]. Special Collections of the Old Dominion University Libraries, Oral Histories in the Perry Library. Retrieved from http://www.lib.odu.edu/specialcollections/oralhistory/index.htm

Richman, R. (2011). Title IX: The Trojan horse in the struggle for female athletic coaches to attain equal opportunities in intercollegiate sports. Virginia Sports \& Entertainment Law Journal, 10(2), 376-413.

Ricoeur, P. (1973). The model of the text: Meaningful action considered as a text. New Literary History, 5(1), 91-117. doi:10.2307/468410

Rollins, A.B. (1999, February 15). Oral history interview with Dr. Alfred B. Rollins [Transcript and audio file]. Special Collections of the Old Dominion University Libraries, Oral Histories in the Perry Library. Retrieved from http://www.lib.odu.edu/specialcollections/oralhistory/index.htm

Rollins accepts presidency at campus meeting. (1976, April 30). UNews. Retrieved from Special Collections of the Old Dominion University Libraries.

Scraton, S., \& Flintoff, A. (2002). Sport feminism: The contribution of feminist thought to our understandings of gender and sport. In S. Scraton \& A. Flintoff (Eds.), Gender and sport: A reader (pp. 30-46). New York: Routledge.

Silbaugh, K. (2015). Reactive to proactive: Title IX's unrealized capacity to prevent campus sexual assault. Boston University Law Review. Boston University. School of Law, 95(3), $1049-1076$.

Spies, J.E. (2006). Winning at all costs: An analysis of a university's potential liability for sexual assaults committed by its student athletes. Marquette Sports Law Review, 16(2), 429-460.

Staurowsky, E.J., Murray, K., Puzio, M., \& Quagliariello, J. (2013). Revisiting James Madison University: A case analysis of program restructuring following so called 'Title IX' cuts. Journal of Intercollegiate Sport, 6(1), 96-119. doi:10.1123/jis.6.1.96 
Stevenson, B. (2007). Title IX and the evolution of high school sports. Contemporary Economic Policy, 25(4), 486-505. doi:10.1111/j.1465-7287.2007.00080.x

Suggs, W. (2005). A Place on the Team. Princeton, NJ: Princeton University Press.

Sullivan, A. (2015). Illegal procedure? Title IX and sexual assault. New England Journal of Higher Education, 1.

Survey of sex discrimination in academe begun. (1976, June 18). UNews. Retrieved from Special Collections of the Old Dominion University Libraries.

Sweeney, J.R. (1980). Old Dominion University: A half century of service. Norfolk, VA: Old Dominion University.

Szczepaniak, M., Pathan, H., Sohail, A., \& Lohar, S.A. (2013). Liberalism and feminism in education. International Journal of Academic Research, 5(6), 266-269.

Title, IX. @ 35. (2007) National Association for Girls and Women in Sport. Oxon Hill, MD: AAHPERD Publications.

Title IX report published. (1977, May 6). UNews. Retrieved from Special Collections of the Old Dominion University Libraries.

University Women's Caucus Records, Box 4, Folder 3: Title IX (1976-77), Special Collections of the Old Dominion University Libraries.

Walker, G. (2010). The evolution and limits of Title IX doctrine on peer sexual assault. Harvard Civil Rights-Civil Liberties Law Review, 45(1), 95-133.

West, M. S., \& Curtis, J. W. (2006). Organizing around gender equity. AAUP Faculty Gender Equity Indicators 2006 1, 1.

Women elect officers. (1975, February 7). UNews. Retrieved from Special Collections of the Old Dominion University Libraries.

Yin, R.K. (2014). Case study research: Design and Methods (5th ed.). Los Angeles: Sage Publishing, Inc.

Zaslow, E., \& Schoenberg, J. (2012). Stumping to girls through pop culture: Feminist interventions to shape future political leaders. Women \& Language, 35(1), 97-116. 